\section{(6) OPEN ACCESS}

${ }^{1}$ Regional Knowledge Hub for HIVIAIDS Surveillance, Institute for Futures Studies in Health, Kerman University of Medical Sciences, Kerman, Iran ${ }^{2}$ DVM, Regional Knowledge Hub for HIVIAIDS Surveillance, Institute for Futures Studies in Health, Kerman University of Medical Sciences, Kerman, Iran ${ }^{3}$ Regional Knowledge Hub for HIVIAIDS Surveillance, Institute for Futures Studies in Health Kerman University of Medical Sciences, Kerman, Iran

\section{Correspondence to}

Dr Ali-Akbar Haghdoost, Regional Knowledge Hub for HIVIAIDS Surveillance, Institute for Futures Studies in Health, Kerman University of Medical Sciences, Kerman, Iran; ahaghdoost@kmu.ac.ir

Received 3 May 2013 Accepted 6 May 2013 Published Online First 8 June 2013

\title{
Why is the number of HIV/AIDS-related publications low in the MENA region?
}

\author{
Maryam Nasirian, ${ }^{1}$ Mohammad Karamouzian, ${ }^{2}$ Ali-Akbar Haghdoost ${ }^{3}$
}

We enjoyed reading Dr Saba's paper ${ }^{1}$ and would like to share some opinions about HIV/AIDS-related publications in the Middle East and North Africa (MENA). This paper showed a positive trend in the number of annual HIV/AIDS-related publications in the MENA. On the other hand, this paper suggests that this number is still very low considering the sharp upward trend of new HIV infections in this region. This gap might be due to several factors. The unsupportive dominant political climate, as well as the stigma and sensitivity surrounding at-risk populations, such as men having sex with men, is very high. ${ }^{2}$ Some of these countries have long been struggling with internal wars, uprisings and terrorism, that may overshadow the importance of this infection in the minds of those in charge.

On the other hand, the dynamics of research have profound pitfalls in the region. The potential research capacity and the availability of funding do differ greatly across the region. ${ }^{2}$ Lack of a clear and comprehensive plan in several countries in this region might also be an influencing factor. Last but not least, scarce publications on HIV/AIDS-related topics may stem from the policy of credited scientific journals in publishing the findings of researchers from this region. Most scientific journals stick to high international research standards (regarding methodology, mainly), while reviewing manuscripts from the MENA region. Some barriers, such as low sample size, presence of selection and information biases to some extent might convince journals to reject the papers from this region. ${ }^{3}$ However, implementation of high-quality studies might be impossible in some of these countries. We think even simple descriptive data using even convenience sampling methods could be an important step forward in enriching the available data in the region. ${ }^{2}$ Out of the formerly mentioned factors, we assume changing the viewpoints of journal editors is one of the most feasible options we have ahead. Lastly, although publishing the findings of researches and studies across the region is of importance, the way and to the extent those findings are applied in the countries to make a change and better the situation is much more vital.

\section{Handling editor Jackie A Cassell \\ Competing interests None.}

Provenance and peer review Not commissioned; internally peer reviewed.

Open Access This is an Open Access article distributed in accordance with the Creative Commons Attribution Non Commercial (CC BY-NC 3.0) license, which permits others to distribute, remix, adapt, build upon this work non-commercially, and license their derivative works on different terms, provided the original work is properly cited and the use is non-commercial. See: http:// creativecommons.org/licenses/by-nc/3.0/

\section{REFERENCES}

1 Saba HF, Kouyoumjian SP, Mumtaz GR, et al. Characterising the progress in HIVIAIDS research in the Middle East and North Africa. Sex Transm Infect 2013;89:iii5-9.

2 Bozicevic I, Riedner G, Garcia Calleja JM. HIV surveillance in MENA: recent developments and results. Sex Transm Infect 2013;89:iii9-14.

3 Mumtaz GR, Hilmi N, McFarland W, et al. Are HIV epidemics among men who have sex with men emerging in the Middle East and North Africa?: a systematic review and data synthesis. PLoS Med 2011;8:e1000444.

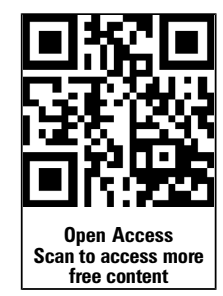

